\title{
Classification of the Tatra Mountain lakes in terms of the duration of their ice cover (Poland and Slovakia)
}

\author{
Bogdan Gądek, ${ }^{*}$ Mirosław Szumny, Bartłomiej Szypuła \\ Institute of Earth Sciences, University of Silesia in Katowice, Będzińska Str. 60, 41-200 Sosnowiec, Poland
}

\begin{abstract}
This paper presents the results of a classification of the Tatra lakes based on the duration of their ice cover, altitude, volume, and potential incoming solar radiation (PISR). It is embedded in the context of the impact of current climate change on the mountain environment. A digital elevation model, morphometric data, satellite imagery from the winter seasons of 2015-2017 and the Wrocław taxonomy method were used in the study. It was found that the order of freezing and thawing of the lakes investigated may change from year to year. The relationship between ice cover duration and altitude is clearly weakened by variations in lake volumes, with insolation having a noticeably lesser effect. Determining the duration of ice cover of the lakes over several seasons facilitates identifying the similarities and dissimilarities between them. Five groups of lakes displaying similar characteristics were identified as well as 2 groups of lakes with highly individual characteristics. Based on the data obtained, it can be concluded that the duration of ice cover on the Tatra lakes has been shortening noticeably over the last 100 years. Small high-altitude lakes seem to be most vulnerable to climate change.
\end{abstract}

\section{INTRODUCTION}

The ice cover of lakes is one of the seasonal components of the cryosphere (Barry and Gun, 2011), and its long-term variability may reflect changes in the Earth's climate (Sharma et al., 2016). By stopping the mixing of water by wind and changing the light conditions and exchange of heat between the water and the atmosphere, the ice cover influences the physical, chemical and biological processes that shape the lake ecosystem (Mishra et al., 2011; Leppäranta, 2010; Krillin et al., 2012; Hampton, 2017; Wang et al., 2018).

Present-day climatic warming (IPCC, 2013) leads to a decrease in the maximum thickness of the ice cover of

Corresponding author: bogdan.gadek@us.edu.pl

Key words: Mountain lakes; lake ice cover; lake classification; Wroclaw taxonomy; climate change implications; Tatra Mts.

Authors' contributions: All the authors made a substantive intellectual contribution, performed part of the experiments. All the authors have read and approved the final version of the manuscript and agreed to be accountable for all aspects of the work.

Edited by: Mariano Bresciani, CNR-IREA Milan, Italy

Received: 17 June 2019

Accepted: 27 November 2019.

This work is licensed under a Creative Commons Attribution NonCommercial 4.0 License (CC BY-NC 4.0).

${ }^{\circ}$ Copyright: the Author(s), 2019

Licensee PAGEPress, Italy

J. Limnol., 2020; 79(1): 70-81

DOI: 10.4081/jlimnol.2019.1920 lakes and to a shortening of its duration. As has been observed, there is a growing tendency for lakes of the Northern Hemisphere to freeze later and thaw earlier, which is related to the shortening of thermal winters (Palecki and Barry, 1985, Magnuson et al., 2000; Hodgkins et al., 2002; Williams et al., 2004; Brown and Duguay, 2010; Benson et al., 2012; Apsite et al., 2014, Kainz, 2017; Sharma et al., 2019). However, lakes may differ significantly in terms of the pace of changes and the duration of the ice cover (Assel et al., 2003; Marszelewski and Skowron, 2006; Weyhenmeyer et al., 2011; Nõges and Nõges, 2014). In addition to local circumstances, the teleconnection conditions may be of great importance (Livingstone, 1997; Choiński et al., 2015a; Van Cleave et al., 2014; Ptak et al., 2019).

The key topographic and morphological determinants of the duration of lake ice cover include, among others, the altitude, surface area, depth and shading of lakes (Šporka et al., 2006; Novikmec et al., 2013). The freezing is largely determined by weather and by internal factors (the lake's surface area and depth), while the thawing depends in the first place on atmospheric conditions (Krillin et al., 2012). For this reason, the ice cover duration differs greatly both in terms of time and space, with many mountain lakes characterised by the "individualism" of ice-related phenomena.

The most widely accepted thermal taxonomy of lakes refers to water mass mixing regimes (Hutchinson and Löffler, 1956; Lewis, 1983; Woolway and Merchant, 2019). However, lakes of the same type in terms of the mixing regime may differ in heat resources, the ice cover duration and sensitivity to climate change, which is attributable to the heterogeneity of lake sizes and properties of the natural environment (Skowron, 2009). In the Tatras, the lakes were divided into classes based on the maximum temperature of surface waters in the 
summer and the duration of the seasonal ice cover in the first half of the $20^{\text {th }}$ century (Lityński, 1917; Szaflarski, 1936). In recent decades, the duration of the ice cover has been found to have been shrinking (Pociask-Karteczka and Choiński, 2012; Choiński et al., 2015b). Gądek and Szypuła (2015) presented the duration of ice cover on the Tatra lakes in the years $1999-2010$ on a 1:250,000 scale map. However, their study is characterised by a low temporal and spatial resolution. Both international and local literature lacks complete and up-to-date data on the variations in the ice cover of lakes and the underlying causes across an entire mountain region.

This paper has prepared a classification of the Tatra lakes combining the duration of their ice cover, altitude, size and shading, which will be useful in geoecological research on the effects of present-day climate change. It also demonstrates how publicly available data can be used to group lakes of any mountain region for typology purposes, e.g. for the needs of detailed reference research and comparisons. In this study, use is made of the digital elevation model (DEM) of the Tatra Mountains, the Solar Radiation module of the Arc GIS software (ESRI, 2017), morphometric data concerning the lakes of the region, satellite imagery from the winter seasons of 2015-2017, and the Wrocław taxonomy method. The cluster analysis method employed allows the lakes to be grouped objectively with no need to first assume the number of classes. In addition, the boundaries between the classes distinguished are measurable and the structure of the similarities between the objects researched is conspicuous (Senetra and Szarek-Iwaniuk, 2019).

\section{Regional settings}

The Tatras are the highest mountain range in the Carpathians (Gerlach: $2655 \mathrm{~m}$ asl). They are located in central Europe between the Alps, the Scandinavian Mountains and the Caucasus (Fig. 1). The Tatras cover an area of about $790 \mathrm{~km}^{2}$ (Balon et al., 2015), about $22 \%$ of which lies in Poland, and the rest in Slovakia.

In the Pleistocene, this area was repeatedly glaciated (Lindner et al., 2003). At the time of maximum spread of the Würmian glaciers, the equilibrium line altitude (ELA) was probably close to $1500 \mathrm{~m}$ asl (Zasadni and Kłapyta, 2014; Engel et al., 2017; Makos et al., 2018). Currently, the upper tree line runs at this altitude, while the presentday climatic snow line $(C S L \approx E L A)$ runs over $1000 \mathrm{~m}$ higher (Zasadni and Kłapyta, 2009). The present-day orographic snow line on the northern side of the Tatra Mountains is marked by the lowest-lying firn-ice patches (nourished by snow avalanches), which has ranged between 1530-1980 $\mathrm{m}$ asl over recent decades (Gądek and Szypuła, 2015). Above the upper tree line, the environment has periglacial features (Rączkowska, 2007; Lajczak et al., 2014).

The present-day climate of the Tatras is transitional between maritime and continental influences. The mean annual air temperature (MAAT) in the northern and southern forelands (around $850 \mathrm{~m}$ asl) is approximately $6^{\circ} \mathrm{C}$ and $8^{\circ} \mathrm{C}$ respectively. On the highest peaks, MAAT is <$2^{\circ} \mathrm{C}$ (Łupikasza and Szypuła, 2019). In the second half of the $20^{\text {th }}$ century and in the first decade of the $21^{\text {st }}$ century, the Tatras recorded an increase in air temperature in winter and summer, as well as a decrease in the total annual snowfall (Żmudzka, 2011; Gądek, 2014). This process has been accompanied by a decrease in the maximum thickness and duration of the snow cover (Falarz, 2002) and the ice cover of lakes (Pociask-Karteczka and Choiński, 2012).

There are 262 lakes in the Tatras (Kopáček et al., 2004), all of which are of post-glacial origin (tarn and morainedammed lakes). Most of them are situated above the altitude of $1800 \mathrm{~m}$ asl. In the central part of the High Tatras, which is built of granitoids, there are 116 large and 105 small lakes (seasonal lakes or lakes $<0.01 \mathrm{ha}$ ), whereas in the Western Tatras, which are built of crystalline rocks,

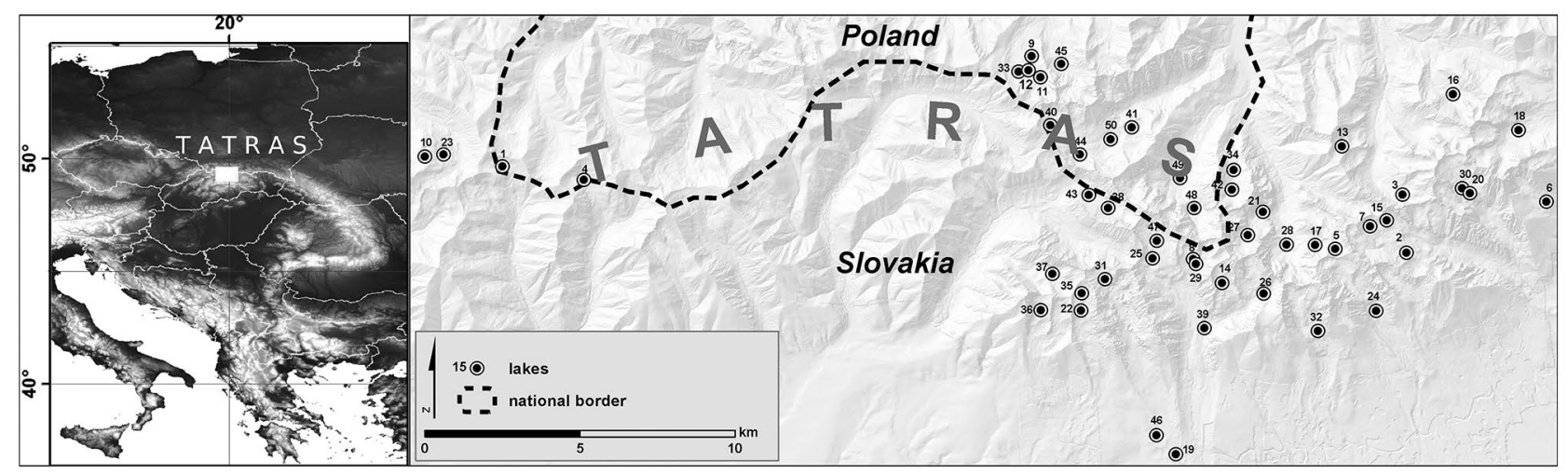

Fig. 1. Location of the study area. 
there are 22 large and 18 small lakes. Most lakes are smaller than 1 ha and up to $2 \mathrm{~m}$ deep. A majority of them are located on the south side of the Tatra Mountains. The largest lakes, Morskie Oko and Wielki Staw Polski, are on the northern side. The surface area of both exceeds 30 ha, and their maximum depths are 51 and $80 \mathrm{~m}$ respectively. The Tatra lakes are usually covered with ice for from 6 to 10 months. In the past, some lakes located at altitudes of more than $2000 \mathrm{~m}$ asl could have an ice cover throughout the year (Pacl and Wit-Jóźwikowa, 1974).

\section{DATA AND METHODS}

The classification of the Tatra lakes was prepared by means of the Wroclaw taxonomy method on the basis of six features: altitude, volume, potential incoming solar radiation (PISR), and the number of days with ice cover in three subsequent seasons (Tab. 1). In this way, account was taken of both external and internal conditions as well as temporal variability in the duration of ice cover, and more significance was given to the latter in the analytical procedure adopted. All features were checked using basic statistical methods.

\section{Data acquisition}

In the study, use was made of a digital elevation model (DEM) of the Tatras with a resolution of 10x10 $\mathrm{m}$ and the vector layer of lakes (shapefile) of the digital map of the hydrographic division of Poland, which also includes the Slovak part of the Tatra Mountains (IMGW, 2007). Based on these, a set of lakes with an area of $>1.0$ ha was identified, the altitudes of these lakes were determined, and the values of annual total potential incoming solar radiation, the amount of solar energy expressed in Watthours per square metre that could reach the areas from each sky direction in a given time (Fu and Rich, 2002), were calculated. The calculations were performed in ArcGIS v. 10.5 using the Solar Radiation tool (ESRI, 2017). Data on the volume of individual lake basins were taken from a study by Gregor and Pacl (2005).

The durations of the ice cover of the individual lakes in the 2014/2015, 2015/2016 and 2016/2017 seasons were determined on the basis of the analysis of the results of 95 Sentinel-2 satellite images and 101 Landsat- 8 images from October-June. The compositions of True/Natural colour and NDWI spectral channels with the resolutions of $20 \mathrm{~m}$ (Sentinel-2) and $30 \mathrm{~m}$ (Landsat) used in this paper are available at: https://apps.sentinel-hub.com. On their basis, the condition of the continuous ice cover was visually assessed on each lake separately. In order to validate the results of the satellite imagery interpretation, use was made of footage from webcams trained on the following lakes: Morskie Oko, Przedni Staw Polski,
Wielki Staw Polski, Zielony Staw Gąsienicowy, Kurtkowiec, Štrbské pleso, Popradské pleso, Velické pleso, and Skalnaté pleso (https://www.panorama.sk/sk/ webkamery/vysoke-tatry/353).

\section{Basic statistics}

The features analysed were examined by checking their distribution (histogram), setting the maximum and minimum values, as well as by calculating the arithmetic means, standard deviations, and coefficients of variation. The interdependence of the features was identified on the basis of the values of Pearson's correlation coefficient together with verification of their statistical significance by means of the $t$-test.

\section{Wroclaw taxonomy}

This method consists of the grouping of multi-feature objects into internally homogenous classes, but which are and heterogeneous between each other. Objects, which are characterised by standardised quantitative features, create a cloud of points of an n-dimensional (number of features) space (Florek et al., 1951). The similarity/dissimilarity of objects is measured by the average difference in their features which is referred to as the taxonomic distance $\left(D_{i j}\right)$ :

$$
D_{i j}=\sum_{k=1}^{n}\left|\frac{X i k-X j k}{n}\right|
$$

where:

$D_{i j}$ - taxonomic distance between objects (lakes) $i$ and $j$ for $i \neq j=1,2, \ldots, m, m$ - number of objects, $x_{i k}$ standardised value of the $k$-feature for the $i$-object for $k=$ $1,2, \ldots, n, x_{j k}$-standardised value of the $k$-feature for the $j$-object, $n$-number of features.

The smaller the taxonomic distance, the greater the similarity between the objects being compared in terms of the features in question. The division of objects into classes can be made on the basis of the critical distance. In order to determine its value, all the Hellwig (1968) criteria were used. However, the best result was achieved with the assumption that the critical distance is equal to the arithmetic mean of the smallest taxonomic distances between lakes.

The basis for the classification of the Tatra lakes was a matrix composed of 50 columns (number of lakes) and 6 rows (number of features). The taxonomic distances between the individual lakes calculated with the use of equation (1) and their classes distinguished on the basis of the critical distance are presented in the form of a dendrite (Fig. 2). The core of each class consists of the two objects (lakes) lying closest to each other within the space of features (the smallest taxonomic distance). The taxonomic distances of the other objects of a given class from its core do not exceed the critical distance. 
Tab. 1. List and characteristics of Tatra lakes with an area of $>1$ ha.

\begin{tabular}{|c|c|c|c|c|c|c|c|c|}
\hline No. & Lake name & $\begin{array}{l}\text { Area } \\
\text { (ha) }\end{array}$ & $\begin{array}{l}\text { Altitude } \\
\text { (m asl) }\end{array}$ & $\begin{array}{l}\text { Volume } \\
\left(\mathrm{m}^{3}\right)\end{array}$ & $\begin{array}{l}\text { PISR } \\
\left(\mathrm{Wh} / \mathrm{m}^{2} / \mathrm{a}\right)\end{array}$ & $\begin{array}{l}\text { No. of days } \\
\text { with a lake } \\
\text { ice cover in } \\
\text { the season } \\
2014 / 2015\end{array}$ & $\begin{array}{l}\text { No. of days } \\
\text { with a lake } \\
\text { ice cover in } \\
\text { the season } \\
2015 / 2016\end{array}$ & $\begin{array}{l}\text { No. of days } \\
\text { with a lake } \\
\text { ice cover in } \\
\text { the season } \\
2016 / 2017\end{array}$ \\
\hline 1 & Nižné Jamnicke pleso & 1.1 & 1732 & 25180 & 1075099,686 & 169 & 177 & 161 \\
\hline 2 & Dlhé pleso & 1.1 & 1894 & 24270 & 960999,8205 & 201 & 180 & 200 \\
\hline 3 & Žabie Javorové pleso & 1.2 & 1878 & 60453 & 854326,5965 & 186 & 194 & 202 \\
\hline 4 & Vyšné Račkove pleso & 1.2 & 1697 & 5624 & 1043923,686 & 169 & 177 & 160 \\
\hline 5 & Zamrznuté pleso & 1.2 & 2040 & 43388 & 938159,4665 & 217 & 209 & 235 \\
\hline 6 & Skalnaté pleso & 1.2 & 1751 & 15874 & 1162806,843 & 161 & 175 & 177 \\
\hline 7 & Pusté plesá & 1.2 & 2056 & 32079 & 1103229,212 & 186 & 193 & 199 \\
\hline 8 & Malé Žabie pleso Mengusovské & 1.2 & 1920 & 45696 & 1103909,838 & 186 & 197 & 190 \\
\hline 9 & Dwoisty Staw Wschodni & 1.3 & 1657 & 48100 & 1103672,174 & 175 & 167 & 162 \\
\hline 10 & Horné Roháčske pleso & 1.4 & 1719 & 46067 & 1002228,743 & 169 & 167 & 173 \\
\hline 11 & Długi Staw Gąsienicowy & 1.5 & 1784 & 81060 & 1008949,999 & 178 & 177 & 233 \\
\hline 12 & Kurtkowiec & 1.6 & 1686 & 34560 & 1083968,218 & 175 & 168 & 163 \\
\hline 13 & Zelené Javorové pleso & 1.5 & 1815 & 17190 & 810268,6638 & 176 & 180 & 169 \\
\hline 14 & Dračie pleso & 1.7 & 2020 & 102835 & 1045336,741 & 192 & 197 & 187 \\
\hline 15 & L'adové pleso Zbojníckie & 1.7 & 2057 & 101133 & 1160836,88 & 199 & 199 & 211 \\
\hline 16 & Kolové pléso & 1.8 & 1565 & 10846 & 939493,3292 & 157 & 161 & 184 \\
\hline 17 & Litvorové pleso & 1.9 & 1860 & 135000 & 930761,8864 & 179 & 211 & 220 \\
\hline 18 & Želené pleso Kežmarské & 1.9 & 1546 & 31755 & 927035,919 & 157 & 157 & 184 \\
\hline 19 & Nové Štrbské pleso & 1.9 & 1312 & 40640 & 1119155,941 & 127 & 129 & 137 \\
\hline 20 & Prostredné Spišské pleso & 1.9 & 2010 & 50193 & 1141339,327 & 175 & 199 & 202 \\
\hline 21 & Ťažké pleso & 2.0 & 1612 & 47722 & 1021253,97 & 162 & 167 & 161 \\
\hline 22 & Nižné Wahlenbergovo pleso & 2.0 & 2053 & 69701 & 1093719,909 & 192 & 200 & 222 \\
\hline 23 & Vel'ké Roháčske pleso & 2.2 & 1562 & 77063 & 997339,884 & 176 & 161 & 157 \\
\hline 24 & Velické pleso & 2.2 & 1666 & 45575 & 1015454,146 & 159 & 139 & 157 \\
\hline 25 & Malé Hincovo pleso & 2.2 & 1921 & 72360 & 1119794,053 & 169 & 180 & 167 \\
\hline 26 & Ladové pleso v Zlomiskách & 2.3 & 1925 & 87397 & 986959,6122 & 192 & 197 & 187 \\
\hline 27 & Zmrzlé pleso & 2.3 & 1762 & 86269 & 794669,716 & 192 & 224 & 183 \\
\hline 28 & Zelené pleso Kačacie & 2.5 & 1575 & 28236 & 865974,7195 & 155 & 160 & 158 \\
\hline 29 & Vel'ké Žabie pleso Mengusovské & 2.7 & 1921 & 73295 & 1046814,331 & 185 & 197 & 188 \\
\hline 30 & Vel’ké Spišské pleso & 2.8 & 2013 & 124591 & 1083257,689 & 179 & 197 & 202 \\
\hline 31 & Capie pleso & 3.2 & 2075 & 163987 & 399647,2955 & 169 & 190 & 170 \\
\hline 32 & Batizovské pleso & 3.5 & 1884 & 232089 & 1148697,566 & 169 & 169 & 168 \\
\hline 33 & Zielony Staw Gąsienicowy & 3.8 & 1672 & 260500 & 1011723,232 & 168 & 168 & 170 \\
\hline 34 & Nižné Bielovodské Žabie pleso & 4.8 & 1675 & 325244 & 1000490,533 & 176 & 168 & 164 \\
\hline 35 & Vyšné Wahlenbergovo pleso & 5.1 & 2157 & 392078 & 1089790,039 & 194 & 193 & 200 \\
\hline 36 & Krivánske Želené pleso & 5.2 & 2013 & 288685 & 1047439,035 & 185 & 184 & 190 \\
\hline 37 & Nižné Terianske pleso & 5.4 & 1940 & 871668 & 1037330,363 & 169 & 184 & 170 \\
\hline 38 & Vyšné Temnosmrečinské pleso & 6.0 & 1725 & 414712 & 897689,141 & 175 & 179 & 168 \\
\hline 39 & Popradské pleso & 7.0 & 1494 & 504380 & 1022673,706 & 155 & 136 & 157 \\
\hline 40 & Zadni Staw Polski & 7.1 & 1890 & 918400 & 1090155,878 & 173 & 156 & 174 \\
\hline 41 & Przedni Staw Polski & 7.8 & 1668 & 1130000 & 1072084,045 & 161 & 155 & 160 \\
\hline 42 & Vyšné Bielovodské Žabie pleso & 9.9 & 1699 & 839413 & 871020,5667 & 169 & 144 & 174 \\
\hline 43 & Nižné Temnosmrečinské pleso & 12.1 & 1677 & 1501500 & 1032904,022 & 172 & 178 & 160 \\
\hline 44 & Czarny Staw Polski & 12.7 & 1772 & 2825800 & 1025477,074 & 165 & 155 & 174 \\
\hline 45 & Czarny Staw Gąsienicowy & 17.9 & 1620 & 3798000 & 964082,7048 & 156 & 155 & 160 \\
\hline 46 & Štrbské pleso & 19.3 & 1347 & 1299400 & 1130067,997 & 131 & 122 & 138 \\
\hline 47 & Vel'ké Hincovo pleso & 20.0 & 1945 & 4091712 & 1095253,329 & 156 & 169 & 173 \\
\hline 48 & Czarny Staw pod Rysami & 20.6 & 1580 & 7761700 & 774008,8202 & 153 & 157 & 160 \\
\hline 49 & Morskie Oko & 33.0 & 1393 & 9904300 & 929704,6406 & 151 & 155 & 157 \\
\hline 50 & Wielki Staw Polski & 34.5 & 1665 & 12967000 & 1074624,602 & 153 & 152 & 153 \\
\hline
\end{tabular}


In order to identify the main features of the lakes in the various classes, the structure of each class was analysed using the method of arithmetic means (Runge, 2007):

$$
I=\frac{X c k}{X m k}
$$

where: $I$ - feature significance index, $x_{c k}$ - arithmetic mean of the $k$-feature of all objects in the class, $x_{m k}$ - arithmetic mean of the $k$-feature of all the objects in the matrix.

The values of the quotient $I>1$ indicate the main features that form the classes that are distinguished.

\section{RESULTS}

Out of the 262 Tatra lakes, 50 have a surface area of $>1$ ha. The duration of their ice cover in 2014-2017 and its relationship with altitude, volume and PISR are shown in Figs. 3 and 4, respectively. Meanwhile the results of the classification of these lakes are shown in Fig. 2.

\section{Ice cover duration vs altitude, volume, and PISR of lakes}

The average number of days with ice cover for the lakes under study was 174 . The shortest duration of ice cover was recorded in the season 2014/2015 (172 days on average), while the longest was in the 2016/2017 season (177 days). The average standard deviation of this feature was 20 days, and the coefficient of variation was $11.65 \%$. Lakes located at the lowest altitudes, Strbské pleso (No. 46) and Nové Štrbské pleso (No. 19), were the shortest covered by ice - from 122 to 137 days. Whereas the small and high-altitude Zamrznuté pleso lake (No. 5) was longest covered by ice - from 217 to 235 days) (Tab. 1). In addition to the number of days with ice cover, the ranks of the individual lakes in the list compiled on the basis of this feature also changed from year to year (Fig. 3). However, the correlation coefficient for ice cover on the lakes in the individual seasons was statistically significant, ranging from 0.74 to 0.83 .

The duration of ice cover in the seasons analysed was primarily correlated with lake altitude (Fig. 4A). In each case, the values of the correlation coefficients were greater than 0.7 . The relationship between the number of days with ice cover and altitude is weakened the most by lake volume (Fig. 4B). It shows a very large spatial diversity. The coefficient of variation of this feature exceeds $244 \%$, but its distribution is not normal, and the standard deviation is more than twice as high as the mean value and amounts to $2,554,714 \mathrm{~m}^{3}$. The correlation coefficient of the number of days with ice cover and the volume of lakes ranged from -0.3 to -0.38 . However, no relationship

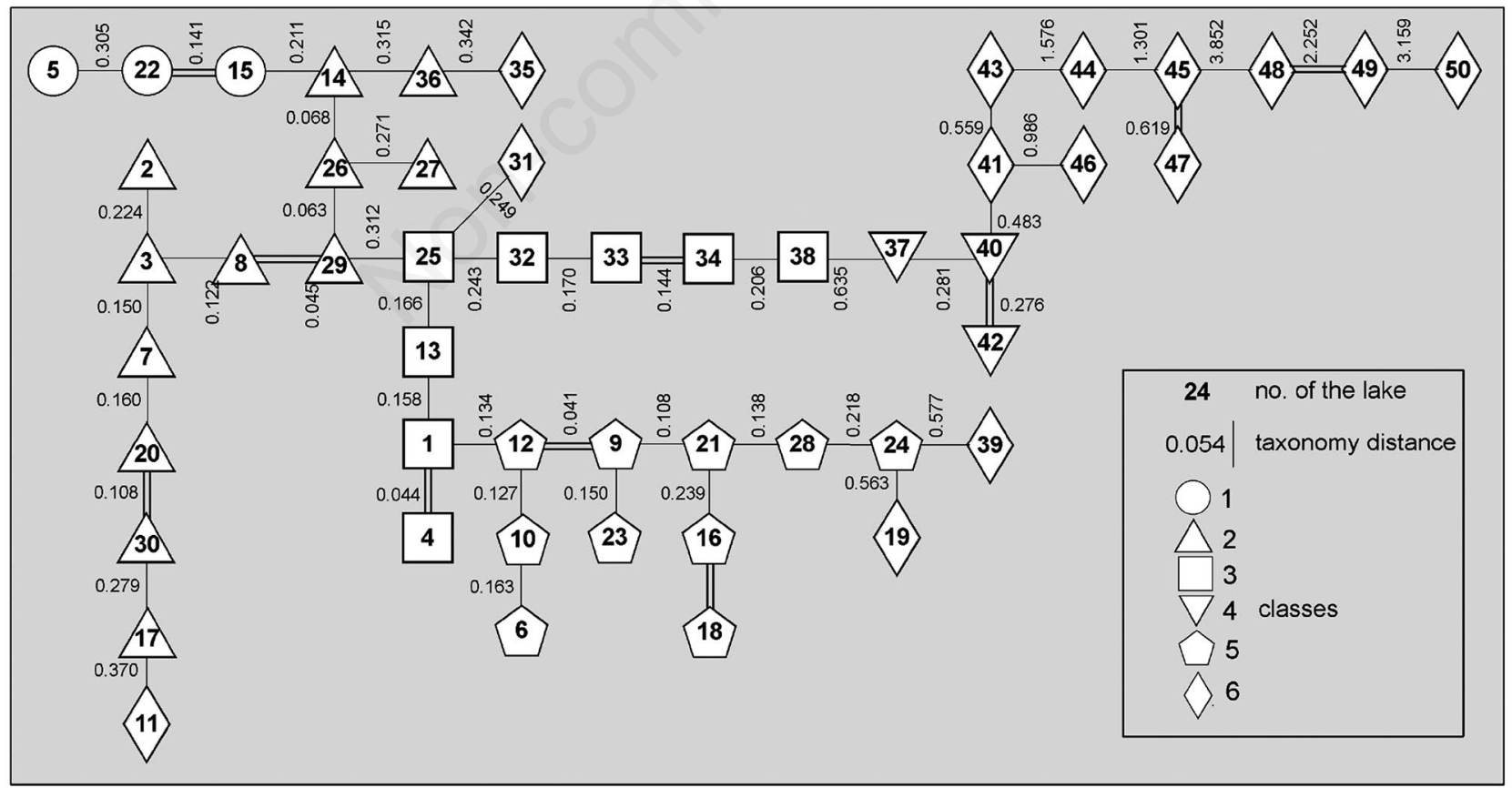

Fig. 2. Results of the classification of the Tatra lakes using the Wrocław taxonomy method (dendrite). Numbers 1-6: lake classes (description in main text); numbering of lakes consistent with their list in Tab. 1; double lines connect the numbers of the lakes which are most similar to each other within the individual classes (cores of the classes); numerical description of the line: taxonomic distance calculated using Equation 1. 

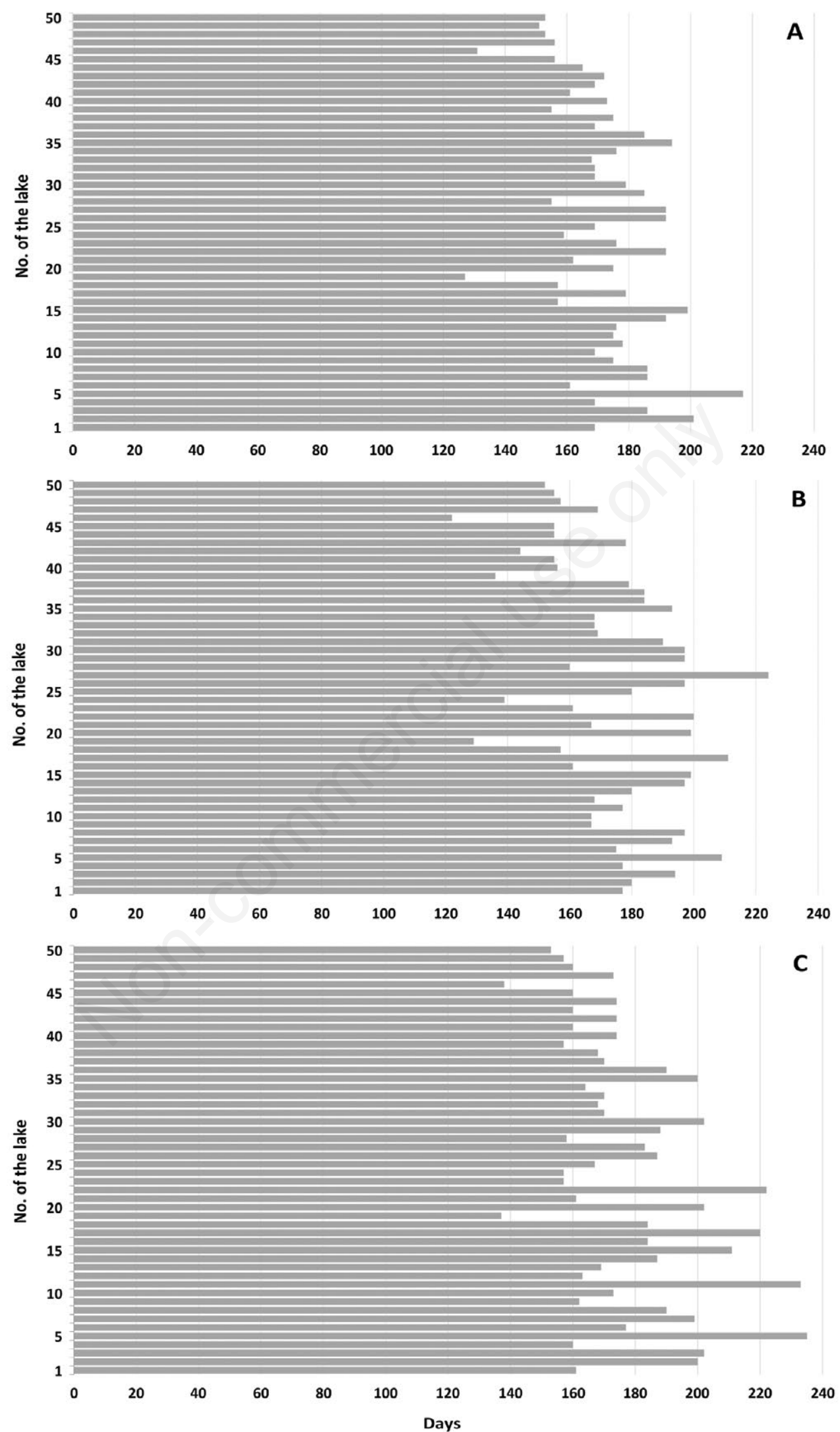

Fig. 3. Duration of the ice cover on the Tatra lakes in the seasons 2014/2015 (A), 2015/2016 (B) and 2016/2017 (C). The numbering of the lakes corresponds with that in the list in Tab. 1. 
was found between the duration of ice cover of the lakes and their annual PISR (Fig. 4C). The values of the correlation coefficients of these features in each of the 3 seasons analysed were close to 0 .

\section{Classification of lakes}

In terms of the features analysed, the lakes Nižné Wahlenbergovo pleso (No.22) and Wielki Staw Polski (No. 50) display the greatest differences, while Dwoisty Staw Wschodni (No. 9) and Kurtkowiec (No. 12) show the greatest similarities. The taxonomic distances between them are 13.54 and 0.04 respectively. The calculated critical distance is 0.43 . On that basis, five classes of lakes were identified and 14 lakes are not similar either to one another or to the lakes assigned to classes 1 to 5 (Fig. 2). The topographical and morphometric differences between the individual groups of lakes (both the classified and unclassified ones) are reflected by the duration of the ice cover.

\section{Class 1}

The group consists of 3 lakes with a small area $(\leq 2$ ha). Their average volume is $71,407 \mathrm{~m}^{3}$. They are situated in the upper, shaded parts of the valleys, at altitudes ranging between 2040 and $2057 \mathrm{~m}$ asl. Against the background of all the lakes that were investigated, this group is distinguished by the smallest average potential solar radiation and the longest duration of ice cover. The average value of potential total solar radiation is 80,572 $\mathrm{Wh} / \mathrm{m}^{2} / \mathrm{a}$, while the average number of days with ice cover over the years 2014-2017 was 209.

\section{Class 2}

The core of this class is formed by the Male Žabie pleso (No. 8) and Vel'ké Žabie pleso (No. 29) lakes. A total of 10 other lakes display significant similarity to these two lakes in terms of the features being studied. All of them are located at altitudes ranging from $1762 \mathrm{~m}$ asl to $2056 \mathrm{~m}$ asl - mostly on the southern side of the main ridge of the Tatras. They are small and medium-sized lakes. Their areas range from 1.1 ha to $5.2 \mathrm{ha}$, and the volume from $24,270 \mathrm{~m}^{3}$ to 288,685 $\mathrm{m}^{3}$. The potential insolation ranges from $33,304 \mathrm{Wh} / \mathrm{m}^{2} / \mathrm{a}$ to $94,172 \mathrm{Wh} / \mathrm{m}^{2} / \mathrm{a}$. The lakes in this class are characterised by a long duration of ice cover. However, in the 3 subsequent study seasons, it was 16 days shorter on average than the duration of the ice cover on class 1 lakes. It fluctuated from 203 to 220 days, with the strongest relationship being demonstrated with the altitude of the lake.

\section{Class 3}

The 8 lakes which form this class are situated at altitudes from $1672 \mathrm{~m}$ asl to $1921 \mathrm{~m}$ asl on both sides of the main ridge. The lakes differ greatly from one another in terms of size. Their area ranges from 1.1 ha to 6 ha, and volume from 5624 to $414,712 \mathrm{~m}^{3}$. The core of this class is formed by the lakes Zielony Staw Gąsienicowy (No.33) and Nižné Bielovodske Žabie pleso (No. 34). The whole group is distinguished by the highest insolation and a very homogeneous duration of ice cover. The average monthly
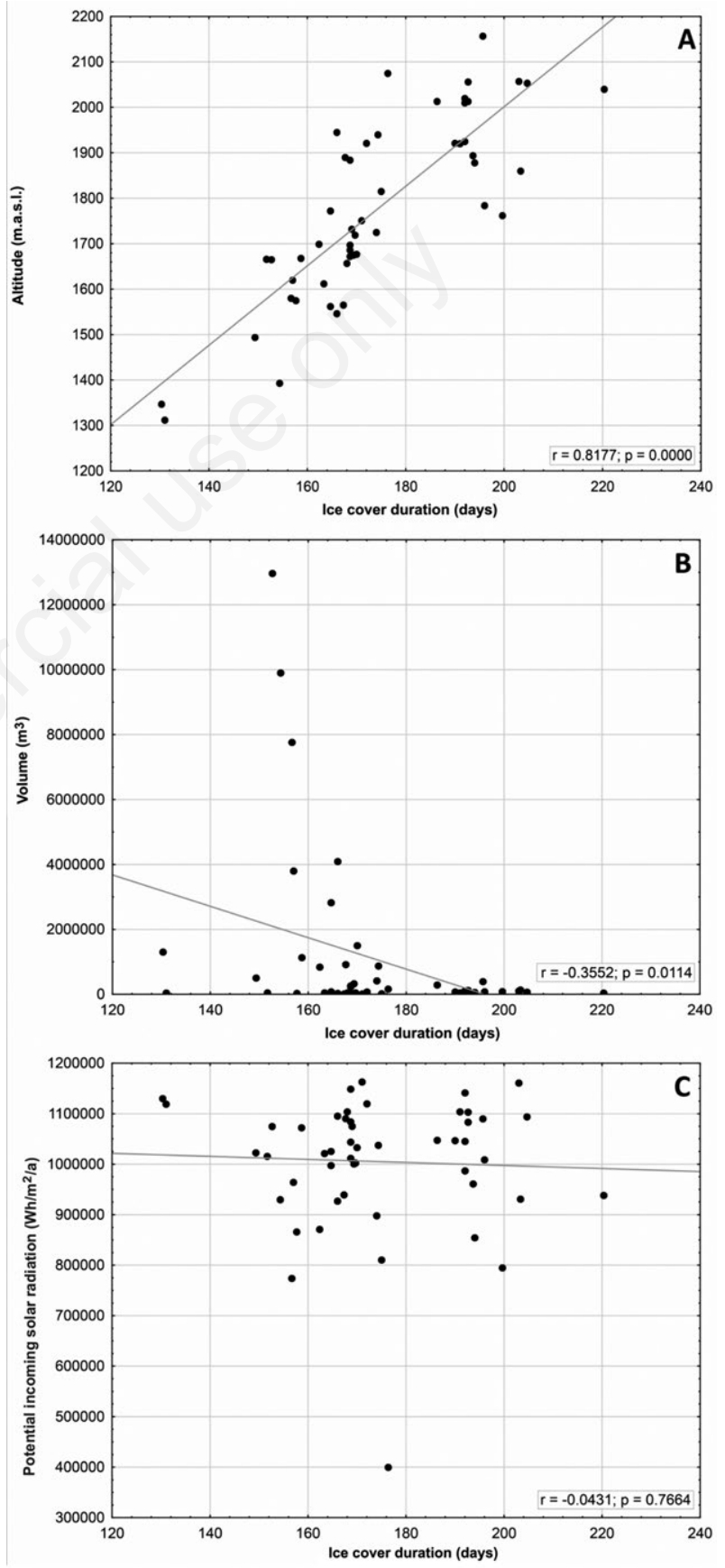

Fig. 4. Relationship between the duration of the ice cover on the Tatra lakes and their altitude (A), volume (B) and potential insolation (C). r, correlation coefficient; $\mathrm{p}$, statistical significance. 
solar radiation is $88,918 \mathrm{Wh} / \mathrm{m}^{2} / \mathrm{a}$. In the years $2014-2017$, the average number of days with ice cover varied on individual lakes from 169 to 175 and was 22 days shorter on average than on class 2 lakes.

\section{Class 4}

This class consists of only 3 lakes. They are located at altitudes between 1670-1940 $\mathrm{m}$ asl, and their potential solar radiation ranges from $71,194 \mathrm{Wh} / \mathrm{m}^{2} /$ a to $87,235 \mathrm{Wh} / \mathrm{m}^{2} / \mathrm{a}$. The average duration of the ice cover fluctuated between 162 and 174 days. In terms of these features, they are similar to class 3 lakes, although they are much larger. Their area ranges from 5.4 ha to 9.9 ha, and the volume from 839,413 to $918,400 \mathrm{~m}^{3}$. In this group of lakes, ice cover duration shows the strongest relationship with altitude.

\section{Class 5}

The core of this class, which consists of 10 items, is represented by Dwoisty Staw Wschodni (No. 9) and Kurtkowiec (No. 12). All the lakes are located at relatively low altitude and are small and shallow. They are situated at altitudes from $1546 \mathrm{~m}$ to $1751 \mathrm{~m}$ asl, their areas range from 1.2 ha to 2.5 ha, and volume from $10,846 \mathrm{~m}^{3}$ to 77,063 $\mathrm{m}^{3}$. The average duration of ice cover of the lakes of this class varied from 152 to 171 days. Their main feature is the relatively high average monthly potential insolation, which ranges from $77,475 \mathrm{Wh} / \mathrm{m}^{2} / \mathrm{a}$ do $95,112 \mathrm{Wh} / \mathrm{m}^{2} / \mathrm{a}$.

\section{Unclassified lakes}

Lakes which are not assigned to any of the classes 1-5 on account of their excessively large taxonomic distance do not form separate classes, but instead represent 14 single-item sets. They are present across a large zone of altitudes ranging from 1311 to $2157 \mathrm{~m}$ asl and are very varied in size. Their area ranges from $1.5 \mathrm{ha}$ to $34.5 \mathrm{ha}$, and the volume from 40,640 to $12,967,000 \mathrm{~m}^{3}$. The average potential solar exposure was $81,684 \mathrm{Wh} / \mathrm{m}^{2} / \mathrm{a}$, and the duration of ice cover ranged from 130 to 196 days. This group includes all lakes with a surface area $>10$ ha (43-50). Thus, the predominant feature of the unclassified lakes is their large volume, which means that the duration of their ice cover is shorter. Among the smaller lakes, Długi Staw Gąsienicowy (No. 11) and Vyšné Wahlenbergovo pleso (No. 35) are most similar to class 2 lakes, Nove Štrbské (No. 19) and Popradské pleso (No. 39) to class 5 lakes, and Capie pleso (No. 31) and Przedni Staw Polski (No. 41) to class 3 and 4 lakes.

\section{DISCUSSION}

The Wrocław taxonomy is one of the oldest and most widely used hierarchical clustering methods (Pedich,
1977; Mercik, Kołodziejczyk; 1986, Senetra and SzarekIwaniuk, 2019). Its results are greatly influenced by the selection of the features of the objects which are compared and the critical distance used. The features on the basis of which objects are grouped should not be strongly correlated with one another (Wierzchoń and Kłopotek, 2018). Of the 6 features used three, i.e. altitude, volume, and potential insolation (the latter mainly depending on shading at the spatial and temporal scales used) are not interrelated at all (Tab. 1) and well characterise the topographic and morphometric conditions of the spatial variability of the duration of the ice cover on the lakes. Meanwhile, even though related to the above features, the duration of the ice cover (Novikmec et al., 2013) depends primarily on the weather conditions, which change over time. Thus, this changes from year to year. The order of the lakes ranked in terms of this feature may also change (Tab. 1). Compared to the volume of the Tatra lakes, the duration of ice cover, altitude and PISR have relatively small variability and thus have a less pronounced effect on the differences between the objects studied. However, given that the classification includes the number of days with ice cover from 3 successive seasons, the resultant division of lakes is logical and warranted when seen in the context of natural processes and considerations.

Given the results of the present classification of lakes and the strong relationship between their thermal characteristics and the duration of ice cover with altitude, and thus with the altitudinal zonation of the climate and vegetation (Mirek and Piękoś-Mirkowa, 1992), we propose that the Tatra lakes (with an area of $>1$ ha) be divided into 7 groups:

(1) small and shaded lakes of the alpine and subnival zones;

(2) small and medium-sized lakes in the upper subalpine and alpine and subnival zones,

(3) small and medium-sized, insolated lakes situated in the upper part of the subalpine zone and in the lower part of the alpine zone;

(4) medium-large, insolated lakes situated in the upper section of the subalpine zone and in the lower section of the alpine zone;

(5) small lakes in the area of the upper tree line and in the lower part of the subalpine zone;

(6) lakes not similar to each other, but showing some similarity to lakes from groups $2-5$,

(7) large lakes ( $>10 \mathrm{ha}$ ) not similar to each other and to lakes from other groups.

The distribution of the thus grouped lakes is shown in Fig. 5. Their numbering increases with the length of the period with no ice cover.

A thermal classification of the Tatra lakes (Szaflarski, 1936) also consists of 7 groups, except that their 
numbering increases with decrease in maximum water temperature. The significant coefficient of correlation in both classifications, which is close to -0.57 , results from the relationship between altitude and duration of ice cover as demonstrated by this study. In these two divisions, only group 5 of our classification and group 3 of the thermal classification (small lakes in the upper tree line zone/lower part of the subalpine zone) are fully consistent. Both groups include the same lakes. In J. Szaflarski's classification, the lakes of the second group have surface areas $<1$ ha, and they were not taken into account in our analysis. In the other cases, the discrepancies are significant (Fig. 6). It should be observed in this context that the classification of Tatra lakes published by J. Szaflarski was based on the compilation of the results of water temperature measurements carried out by him and other authors in different summer seasons. The study comprised a total of 29 lakes, of which only 19 have an area of $>1$ ha. In addition, some of the lakes assigned by J. Szaflarski to the various groups do not meet the classification criteria adopted by him. Furthermore, the study does not take into account the individual characteristics of many lakes.

The data about the ice cover of the Tatra lakes obtained through remote sensing can be compared to 1910-2010 data, which, however, only covers a dozen or so lakes altogether. As is revealed by the latter data (Fig. 7), in the early decades of the 20th century (Lityński, 1914; Pacl and Wit-Jóźwik, 1974; Gregor and Pacl, 2005), ice covered the Tatra lakes for ca. two more months on average than in the years 2014-2017. The largest and smallest differences in the duration of ice cover were observed for class 1 high-altitude lakes (Zamrznuté pleso) and for unclassified low-lying, moraine and anthropogenic lakes (Štrbské plesa). However, it must be considered that efforts to document ice phenology undertaken in the Tatras in the early $20^{\text {th }}$ century were far from systematic. In addition, the selection of lakes monitored in a given season was not always the same. Nevertheless, recent decades have not seen such longlasting ice covers on the highest-lying lakes as at the time, which is consistent with the global multi-century trend of variability in ice cover (Sharma et al., 2016). Compared to the 1999-2010 figures (Gądek and Szypuła, 2015), it can be seen that the ice cover on the lakes with an area $>7$ ha, mainly unclassified ones, lasted by an average of 2 weeks longer in the years 2014-2017. These observations correspond to the results of the monitoring of the ice cover on Morskie Oko conducted by the Institute of Meteorology and Water Management (IMGW) since 1971 (Choiński et al., 2013; Gądek, 2014; Choiński et al., 2015b; Wrzesiński et al., 2016, Ptak et al., 2017). The 1971-1979 data of the IMGW on the duration of the ice cover on Morskie Oko and Wielki Staw Polski (Choiński, 2017) confirm the interannual changes in the order of lakes ranked according to ice cover duration. The data shows that sometimes the ice cover on Wielki Staw Polski lasted for a shorter period than that on Morskie Oko, even though the former is located almost $270 \mathrm{~m}$ higher. Both the order of the freezing and of the thawing of both lakes changed. Notwithstanding the above changes, the average gradient of altitudinal ice cover duration did not show great variability over the last 100 years. Data obtained in the early 20th century (Lityński, 1914) prove that the gradient was close to 11 days $/ 100 \mathrm{~m}$, which means that it did not diverge much from the value determined in this

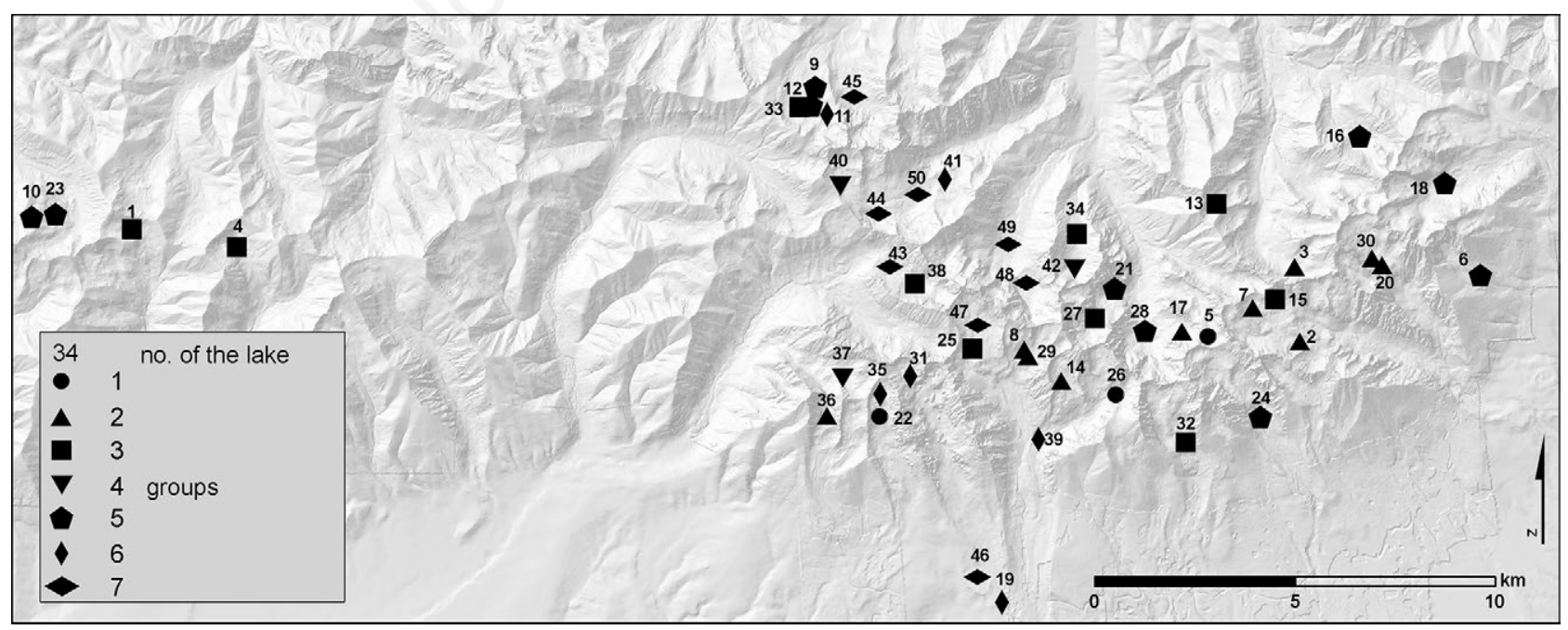

Fig. 5. Locations and groups of Tatra lakes. Numbers 1-7: lake groups (description in main text); numbering of lakes in accordance with the list in Tab. 1. 
study, even though the number of lakes considered, the methods and the accuracy of observations in both cases were different. Also in the 2000/2001 season, the gradient exceeded 10 days/100 m (Šporka et al., 2006).

The data obtained do not seem to confirm the relationship between ice cover duration and potential solar radiation identified by Novikmec et al. (2013). The correlation coefficient for these features was of a very low value. This may be attributable to the spatio-temporal variability of the local conditions of thermal balance of the lakes and of the development of ice cover (Blenckner, 2005). This variability is manifested, inter alia, by variations in the dates and order of freezing and thawing of

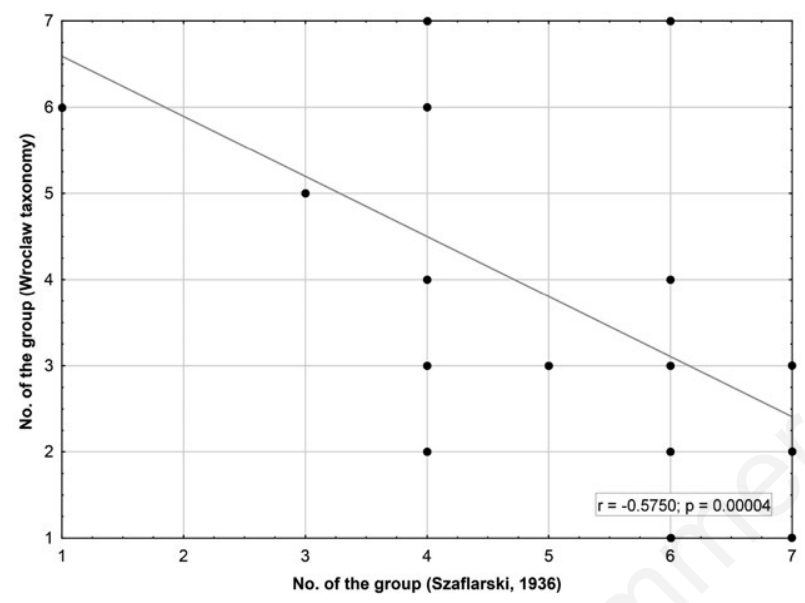

Fig. 6. Relationship between the lake groups determined by means of the Wroclaw taxonomy and by Szaflarski (1936); black circles and numbers assigned to them: lake groups numbered in accordance with the list in Tab. 1. r, correlation coefficient; $p$, statistical significance.

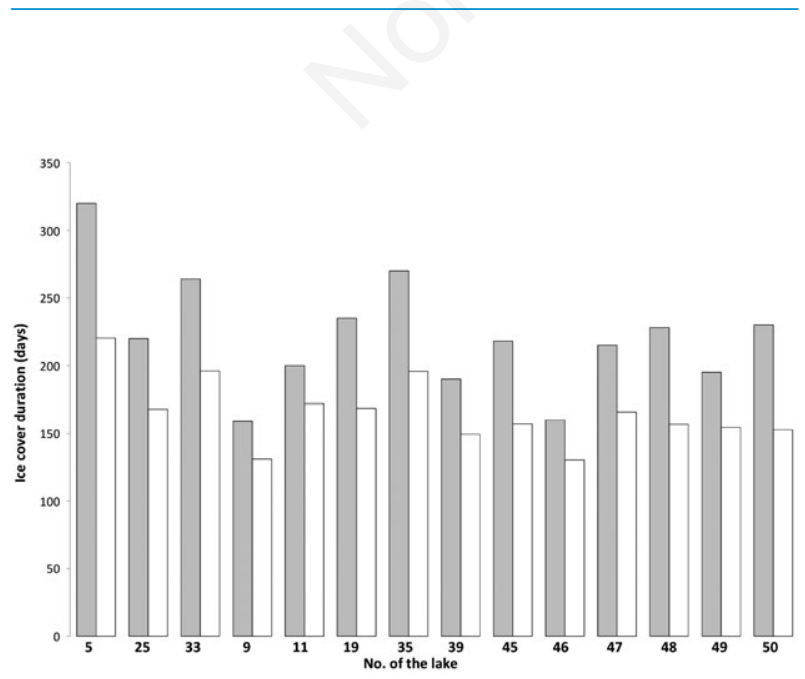

Fig. 7. Ice cover duration in the early decades of the $20^{\text {th }}$ century (grey bars) and in 2014-2017 (white bars). The numbering of the lakes corresponds with the list in Tab. 1. the lakes. The values of the annual totals of potential solar radiation calculated by us and by Novikmec et al. (2013) were very similar. The discrepancies stemmed from the different resolutions of the numerical terrain models. The DEM we used had a resolution of $10 \times 10 \mathrm{~m}$, while Novikmec et al. (2013) used a model with a resolution of 20x20 m. However, by using the Wrocław taxonomy method, we found that low insolation is one of the important features of group 1 lakes, while high solar radiation is characteristic of lakes in group 3 of the above classification.

\section{CONCLUSIONS}

1. High-mountain lakes can be grouped on the basis of the similarity of their altitude, morphometry and topographical conditions. These features are reflected by the duration of the ice cover of the lakes. However, many lakes can be characterised by far-reaching individuality (they are dissimilar from other lakes). In the Tatras, this is mainly seen with the largest lakes.

2. The strongest relationship displayed is that of ice cover duration with altitude. The relationship is noticeably weakened by variations in the volume of the lakes. Solar radiation can also have an effect on the duration of ice cover. Notably, the order of freezing and thawing of mountain lakes can also change from year to year. Therefore, determining the duration of the ice cover of lakes over several seasons facilitates the identification of the similarities and dissimilarities between them.

3. The duration of the ice cover on the Tatra lakes has been noticeably shortening over the last 100 years. The most rapid changes seem to be on small, highaltitude lakes. However, this observation needs to be verified.

\section{ACKNOWLEDGMENTS}

The authors wish to thank colleagues from the Institute of Earth Sciences of the University of Silesia in Katowice - Sławomir Sitek for his consultation on cluster analysis methods, and Tadeusz Molenda for discussions related to limnology. We also thank two anonymous reviewers for their kind contribution to the improvement in the quality of this paper. Last but not least, we are grateful to Mariano Bresciani for his understanding and great commitment to the editorial work.

\section{REFERENCES}

Apsite E, Elferts D, Zubaničs A, Latkovska I, 2014. Longterm changes in hydrological regime of the lakes in Latvia. Hydrol. Res. 45:308-321. 
Assel R, Cronk K, Norton D, 2003. Recent trends in laurentian great lakes ice cover. Clim. Chang. 57: 185-204.

Balon J, Jodłowski M, Krąż P, 2015. Tatra Mountains Topography. In: Atlas of the Tatra Mountains. Abiotic Nature, sheet I.3, Tatrzański Park Narodowy, Zakopane.

Barry R, Gan TY, 2011. The global cryosphere. Past, present, and future. Cambridge University Press, Cambridge: 472 pp.

Benson BJ, Magnuson JJ, Jensen OP, Card VM, Hodgkins G, Korhonen J, Livingstone DM, Stewart KM, Weyhenmeyer GA, Granin NG, 2012. Extreme events, trends, and variability in Northern Hemisphere lake-ice phenology (1855-2005). Clim. Chang. 112:299-323.

Blenckner T, 2005. A conceptual model of climate-related effects on lake ecosystems. Hydrobiologia 533:1-14.

Brown LC, Duguay CR, 2010. The response and role of ice cover in lake-climate interactions. Prog. Phys. Geogr. 34:671-704

Choiński A, 2017. Ice phenomena on Lake Wielki Staw in the Valley of Five Polish Lakes. Limnol. Rev. 17:71-77.

Choiński A, Ptak M, Skowron R, Strzelczak A, 2015a. Changes in ice phenology on Polish lakes from 1961-2010 related to location and morphometry. Limnologica 53:2-49.

Choiński A, Ptak M, Strzelczak A, 2013. Areal variation in ice cover thickness on lake Morskie Oko (Tatra Mountains). Carpath. J. Earth. Env. 8:97-102.

Choiński A, Ptak M, Strzelczak A, 2015b. Changeability of accumulated heat content in Alpine-type lakes. Pol. J. Environ. Stud. 24:2363-2369.

Engel Z, Mentlík P, Braucher R, Křížek M, Pluháčková M, Aster Team, 2017. ${ }^{10} \mathrm{Be}$ exposure age chronology of the last glaciation of the Roháčská Valley in the Western Tatra Mountains, central Europe. Geomorphology 293:130-142.

ESRI 2017. ArcGIS Desktop: Release 10.5. Redlands, CA.

Falarz M, 2002. [Klimatyczne przyczyny zmian i wieloletniej zmienności występowania pokrywy śnieżnej w polskich Tatrach].[Article in Polish]. Prz. Geogr. 74:83-106.

Florek K, Lukaszewicz J, Perkal J, Steinhaus H, Zubrzycki S, 1951. [Taksonomia wrocławska].[Article in Polish]. Prz. Antropol. 17:193-211.

Fu P, Rich PM, 2002. A geometric solar radiation model with applications in agriculture and forestry. Comput. Electron. Agric. 37:25-35.

Gądek B, 2014. Climatic sensitivity of the non-glaciated mountains cryosphere (Tatra Mts., Poland and Slovakia). Glob. Planet. Chang. 121:1-8.

Gądek B, Szypuła B, 2015. Contemporary cryosphere. In: Atlas of the Tatra Mountains. Abiotic Nature, sheet, V.1, Tatrzański Park Narodowy, Zakopane.

Gregor V, Pacl J, 2005. [Hydrológia tatranských jazier].[Article in Slovak]. Acta Hydrol. Slovac. 6:161-187.

Hampton SE, Galloway AWE, Powers SM, Ozersky T, Woo KH, Batt RD, Labou SG, O'Reilly CM, Sharma S, Lottig NR, Stanley EH, North RL, Stockwell JD, Adrian R, Weyhenmeyer GA, Arvola L, Baulch HM, Bertani I, Bowman Jr. LL, Carey CC, Catalan J, Colom $\square$ Montero W, Domine LM, Felip M, Granados I, Gries C, Grossart HP, Haberman J, Haldna M, Hayden B, Higgins SN, Jolley JC, Kahilainen KK, Kaup E, Kehoe MJ, MacIntyre S, Mackay AW, Mariash HL, McKay RM, Nixdorf B, Nõges P, Nõges T, Palmer M, Pierson D, Post DM, Pruett MJ, Rautio M,
Read JS, Roberts SL, Rücker J, Sadro S, Silow EA, Smith DE, Sterner RW, Swann GEA, Timofeyev MA, Toro M, Twiss MR, Vogt RJ, Watson SB, Whiteford EJ, Xenopoulos MA, 2017. Ecology under lake ice. Ecol. Lett. 20:98-111.

Hellwig Z, 1968. [Zastosowanie metody taksonomicznej do typologicznego podziału krajów ze względu na poziom ich rozwoju oraz zasoby i strukturę wykwalifikowanych kadr].[Article in Polish]. Prz. Stat. 4:307-26.

Hodgkins GA, James IC, Huntington TG, 2002. Historical changes in lake ice-out dates as indicators of climate change in New England. Int. J. Climatol. 22:1819-1827.

Hutchinson GE, Löffler H, 1956. The thermal classification of lakes. P. Natl. Acad. Sci. USA 42:84-86.

IMGW (Institute of Meteorology and Water Management), 2007. Mapa podziału hydrologicznego Polski (Map of hydrological division of Poland). Zakład Hydrografii i Morfologii Koryt Rzecznych, IMGW, Warsaw.

IPCC, 2013. Climate Change 2013: The physical science basis. Contribution of Working Group I to the Fifth Assessment Report of the Intergovernmental Panel on Climate Change. Cambridge University Press, Cambridge: 1535 pp.

Kopáček J, Hardekopf D, Majer M, Pšenáková P, Stuchlík E, Veselý J, 2004. Response of alpine lakes and soils to changes in acid deposition: the MAGIC model applied to the Tatra Mountains region, Slovakia-Poland. J. Limnol. 63:143-156. doi: 10.4081/jlimnol.2004.143.

Kainz MJ, Ptacnik R, Rasconi S, Hager HH, 2017. Irregular changes in lake surface water temperature and ice cover in subalpine Lake Lunz, Austria. Inland Waters 7:27-33.

Kirillin G, Leppäranta M, Terzhevik A, Granin N, Bernhardt J, Engelhardt Ch, Efremova T, Golosov S, Palshin N, Sherstyankin P, Zdorovennova G, Zdorovennov R, 2012. Physics of seasonally ice-covered lakes: a review. Aquat. Sci. 74:59-682.

Lajczak A, Margielewski W, Raczkowska Z, Swiechowicz J, 2014. Contemporary geomorphic processes in the Polish Carpathians under changing human impact. Episodes 37:21-32.

Leppäranta M, 2015. Freezing of lakes and the evolution of their ice cover. Springer, Dordrecht: $301 \mathrm{pp}$.

Leppäranta M, 2010. Modelling the formation and decay of lake ice, p. 63-83. In: D.G. George (ed.), The impact of climate change on European lakes. Springer, Dordrecht.

Lewis WM, 1983. A revised classification of lakes based on mixing. Can. J. Fish. Aquat. Sci. 40:1779-1787.

Lindner L, Dzierżek J, Marciniak B, Nitychoruk J, 2003. Outline of Quaternary glaciations in the Tatra Mts., their development, age, and limits. Geol. Quat. 47:269-280.

Lityński A, 1914. [O temperaturze stawów tatrzańskich].[Article in Polish]. Pamięt. Tow. Tatr. 35:69-73.

Lityński A, 1917. [Jeziora tatrzańskie i zamieszkująca je fauna wioślarek].[Article in Polish]. Spraw. Kom. Fizjogr. PAU 51:1-88.

Livingstone D M, 1997. Break-up dates of alpine lakes as proxy data for local and regional mean surface air temperatures. Clim. Chang. 37:407-439.

Łupikasza E, Szypuła B, 2019. Vertical climatic belts in the Tatra Mountains in the light of current climate change. Theor. Appl. Clim. 136:249-264.

Magnuson JJ, Robertson DM, Benson BJ, Wynne RH, Livingstone DM, Arai T, Assel RA, Barry RG, Card VV, 
Kuusisto E, Granin NG, Prowse TD, Stewart KM, Vuglinski VS, 2000. Historical trends in lake and river ice cover in the northern hemisphere. Science 289:1743-1746.

Makos M, Rinterknecht V, Braucher R, Tołoczko-Pasek A, Aster Team, 2018. Last Glacial Maximum and Lateglacial in the Polish High Tatra Mountains - Revised deglaciation chronology based on the ${ }^{10} \mathrm{Be}$ exposure age dating. Quat. Sci. Rev. 187:130-156.

Marszelewski W, Skowron R, 2006. Ice cover as an indicator of winter air temperature changes: case study of the Polish Lowland lakes. Hydrolog. Sci. J. 51: 36-349.

Mercik JW, Kołodziejczyk W, 1986. Taxonomy approach to a cabinet formation problem. Math. Soc. Sci. 12:159-167.

Mirek Z, Piękoś-Mirkowa H, 1992. Plant cover of the Polish Tatra Mountains (S. Poland). Veröff. Geobot. Inst. ETH, Stiftung Rubel, Zürich 707:177-199.

Mishra V, Cherkauer KA, Bowling LC, Huber M, 2011. Lake ice phenology of small lakes: impacts of climate variability in the Great Lakes region. Glob. Planet Chang. 76:166-185.

Novikmec M, Svitok M, Kočický D, Šporka F, Bitušík, P, 2013. Surface water temperature and ice cover of Tatra Mountains lakes depend on altitude, topographic shading, and bathymetry. Arct. Antarct. Alp. Res. 45:77-87.

Nõges P, Nõges T, 2014. Weak trends in ice phenology of Estonian large lakes despite significant warming trends. Hydrobiologia 731: 5-18.

Pacl J, Wit-Jóźwik K, 1974. [Teplota wod], p. 181-204. In: M. Konček (ed.), [Klimat Tatr].[Book in Slovak]. Vydavatel'stvo Slovenskej Akadémie Vied, Bratislava.

Palecki M A, Barry RG, 1985. Freeze-up and break-up of lakes as an index of temperature changes during the transition sasons: a case study for Finland. J. Appl. Meteorol. 25:893-902.

Pedich W, 1977. Application of Wroclaw taxonomy for evaluation of the similarity between electrocardiograms from twins. Adv. Cardiol. 19:42-3.

Pociask-Karteczka, J, Choiński A, 2012. Recent trends in ice cover duration for lake Morskie Oko (Tatra Mountains, EastCentral Europe). Hydrol. Res. 43:500-506.

Ptak M, Wrzesiński D, Choiński A, 2017. Long-term changes in the hydrological regime of high mountain Lake Morskie Oko (Tatra Mountains, Central Europe). J. Hydrol. Hydromech. 65:146-153.

Ptak M, Tomczyk AM, Wrzesiński B, Bednorz E, 2019. Effect of teleconnection patterns on ice conditions in lakes in lowland Poland. Theor. Appl. Climatol. 138:1961-1969.

Rączkowska Z, 2007. Współczesna rzeźba peryglacjalna wysokich gór Europy. Pr. Geogr. PAN IGiPZ 212, Warszawa.

Runge J, 2007. [Metody badań w geografii społecznoekonomicznej].[Book in Polish]. Wydaw. Uniw. Śląskiego, Katowice: 704 pp.

Senetra A, Szarek-Iwaniuk P, 2019. The implementation of the Wroclaw taxonomic method for the identification and evaluation of problem areas in the Warmia and Mazury region in Poland - a case study. Socio-Econ. Plan. Sci. 67C:43-57.

Sharma S, Magnuson JJ, Batt RD, Winslow LA, Korhonen J, Aono Y, 2016. Direct observations of ice seasonality reveal changes in climate over the past $320-570$ years. Sci. Rep. 6:25061.

Sharma S, Blagrave K, Magnuson JJ, O’Reilly CM, Oliver S, Batt RD, Magee MR, Straile D, Weyhenmeyer GA, Winslow L, Woolway RI, 2019. Widespread loss of lake ice around the Northern Hemisphere in a warming world. Nat. Clim. Change. 9:227-231.

Skowron R, 2009. Criteria of thermal classifications of lakes. Bull. Geogr. 2:93-108.

Šporka F, Livingstone DM, Stuchlík E, Turek J, Galas J, 2006. Water temperatures and ice cover in lakes of the Tatra Mountains. Biol. Bratislava 61:77-90.

Szaflarski J, 1936. [Nouvelles études sur le régime thermique des lacs de la Haute-Tatra].[Article in French]. Rev. Geogr. Alp. 24:369-380.

Wang W, Lee X, Xio W, Liu S, Schultz N, Wang Y, Zhang M, Zhao L, 2018. Global lake evaporation accelerated by changes in surface energy allocation in a warmer climate. Nat. Geosci. 11:410-414.

Weyhenmeyer GA, Livingstone DM, Meili M, Jensen O, Benson B, Magnuson JJ, 2011. Large geographical differences in the sensitivity of ice-covered lakes and rivers in the Northern Hemisphere to temperature changes. Glob. Change Biol. 17:268-275.

Wierzchoń ST, Kłopotek MA, 2018. Modern algorithms of cluster analysis. Springer, Cham: $421 \mathrm{pp}$.

Williams G, Layman KL, Stefan HG, 2004. Dependence of lake ice on climate, geographic and bathymetric variables. Cold Reg. Sci. Technol. 40:145-164.

Woolway RI, Merchant ChJ, 2019. Worlwide alteration of lake mixing regimes in response to climate change. Nat. Geosci. 12:271-276.

Wrzesiński D, Choiński A, Ptak M, 2016. Effect of North Atlantic Oscillation on the hydrological conditions of Lake Morskie Oko (Carphatian Mountains). Bull. Geogr. 10:95105.

Van Cleave K, Lenters JD, Wang J, Verhamme EM, 2014. A regime shift in Lake Superior ice cover, evaporation, and water temperature following the warm El Nino winter of 1997-1998. Limnol. Oceanogr. 59:1889-1898.

Zasadni J, Kłapyta P, 2009. An attempt to assess the modern and little Ice Age climatic snowline altitude in the Tatra Mountains. Landf. Anal. 10:124-133.

Zasadni J, Kłapyta P, 2014. The Tatra Mountains during the last glacial maximum. J. Maps 10:440-456.

Żmudzka E, 2011. Contemporary climate changes in the high mountain part of the Tatras. Misc. Geogr. 15:93-102. 